\title{
Aktivitas Antioksidan dan Sitotoksik Ekstrak Etanol Daun hantap (Sterculia coccinea Jack.)
}

\section{(Antioxidant and Cytotoxic Activity of Ethanolic Extract of Hantap Leaves (Sterculia coccinea Jack.))}

\author{
Rezki Cahyani $^{1 *}$, Yuliet susanto ${ }^{2}$, Akhmad Khumaidi ${ }^{3}$ \\ ${ }^{1}$ Jurusan Farmasi, FMIPA, Universitas Tadulako, Palu. \\ ${ }^{2}$ Lab. Farmakologi-Biofarmasi, Jurusan Farmasi, FMIPA, Universitas Tadulako, Palu. \\ ${ }^{3}$ Lab. Farmakognosi-Fitokimia, Jurusan Farmasi, FMIPA, Universitas Tadulako, Palu
}

\begin{abstract}
Hantap (Sterculia coccinea Jack) is one of the plants in Central Sulawesi which has potential as an antioxidant, that can be used to treat a variety of diseases. This study aimed to determine the $\mathrm{IC}_{50}$ values of ethanolic extract of hantap leaves, by DPPH (1,1-diphenyl-2picrylhydrazyl) method, $\mathrm{LC}_{50}$ by Brine Shrimp Lethality Test (BSLT) method and determine its chemical compound. Extract prepared by using ethanol $96 \%$ in maceration method. Determinations of chemical content was done using reagent identification and thin layer chromatography (TLC). Result of the antioxidant activity test of ethanolic extracts of leaves hantap obtained $\mathrm{IC}_{50}$ values of $6.48 \mathrm{ppm}$ and vitamin C (Positive control) of $2.71 \mathrm{ppm}$, while the values of cytotoxic activity $\mathrm{LC}_{50}$ was $591.561 \mathrm{ppm}$. Identification results using reagent and TLC showed that, the extract contains flavonoids, phenols, saponins, steroids, alkaloids, and tannins. Based on the ethanolic extract of hantap leaves categorized as a very strong antioxidants. Whereas cytotoxic activity in the medium category.
\end{abstract}

L.

Keywords: Sterculia coccinea Jack, antioxidant, DPPH, Cytotoxic, Artemia salina

\begin{abstract}
ABSTRAK
Hantap (Sterculia coccinea Jack) merupakan salah satu tumbuhan di Sulawesi Tengah yang mempunyai potensi sebagai antioksidan sehingga dapat dimanfaatkan untuk mengobati berbagai macam penyakit. Penelitian ini bertujuan untuk menentukan nilai $\mathrm{IC}_{50}$ ekstrak etanol daun hantap dengan metode DPPH dan LC $_{50}$ dengan metode BSLT serta mengetahui kandungan kimianya.Ekstrak dibuat dengan metode maserasi menggunakan pelarut etanol 96\%.Penentuan kandungan kimia dilakukan dengan menggunakan pereaksi identifikasi dankromatografi lapis tipis (KLT).Uji aktivitas antioksidan ekstrak etanol daun hantap diperoleh nilai $\mathrm{IC}_{50}$ sebesar $6,48 \mathrm{ppm}$ dan vitamin $\mathrm{C}$ (kontrol positif) 2,71 ppm, sedangkan aktivitas sitotoksiknya dihasilkan nilai $\mathrm{LC}_{50}$ sebesar 591,561 ppm. Hasil identifikasi dengan pereaksi identifikasi dan KLT menunjukkan ekstrak mengandung flavonoid, fenol, saponin, steroid, alkaloid, dan tanin. Berdasarkan hasil uji, ekstrak etanol daun hantap dapat dikatakan memiliki aktivitas antioksi dan yang sangat kuat, sedangkan aktivitas sitotoksiknya masuk kategori sedang.
\end{abstract}

\section{Kata kunci: Daun Hantap (Sterculia coccinea Jack.), Antioksidan, DPPH, Sitotoksik, Artemia salina L}




\section{PENDAHULUAN}

Pemanfaatan tumbuhan obat untuk mengobati berbagai jenis penyakit semakin disukai masyarakat karena relatif jarang menimbulkan efek samping yang tidak diinginkan. Salah satu pemanfaatannya yang signifikan adalah untuk terapi kanker.Penyakit kanker dikenal sebagai penyakit yang sukar disembuhkan dan dapat menyebabkan kematian bila telah mencapai stadium lanjut, sehingga merupakan masalah yang cukup sulit dalam bidang pengobatan. Walaupun telah cukup banyak ditemukan obat kemoterapi untuk pengobatan kanker, namun hasilnya belum memuaskan, karena disamping senyawa aktifnya kurang atau tidak selektif dalam membunuh sel-sel kanker, juga sering menimbulkan efek samping yang cukup besar.Kondisi seperti itu mendorong masyarakat melakukan pengobatan alternatif ataupun komplementer dengan menggunakan bahan alam atau obat tradisional.

Salah satu tanaman obat yang digunakanmasyarakat Donggala, Sulawesi Tengah sebagai obat tradisionaladalah tanaman hantap (Sterculia coccinea Jack.), famili Malvaceae.Secara empiris daun hantap direbus dan diminum untuk mengobati berbagai penyakit kanker, seperti kanker payudara, kanker otak, kanker darah (leukemia), kanker rahim dan kanker prostat (Effendi, 2010).

Hasil penelitian Effendi (2010) menyatakan bahwa daun hantap mengandung tanin, steroid, dan alkaloid. Senyawa metabolit sekunder yang terdapat pada daun hantap diduga dapat berkhasiat sebagai antioksidan dan antikanker.

Penelitian ini bertujuan untuk menentukan nilai $\mathrm{IC}_{50}$ (Inhibition concentration 50) ekstrak etanol daun hantap (Sterculia coccinea Jack.) menggunakan metode DPPH (1,1diphenyl-2-picrylhydrazyl) dan mengetahui

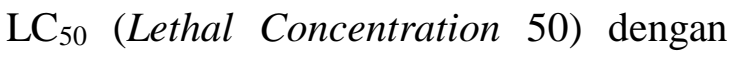
metode BSLT (Brine Shrimp Lethality Test) menggunakan bioindikator Artemia salina L serta mengetahui komponen kimia ekstrak dengan pereaksi identifikasi dan KLT.

\section{METODE}

\section{Bahan}

Daun hantap (S.coccinea Jack.) yang digunakan pada penelitian ini diperoleh dari Kelurahan Panau, Kecamatan Sigi Biromaru, Kabupaten Sigi (hasil pemekaran kabupaten Donggala), Provinsi Sulawesi Tengah, yang sebelumnya telah diidentifikasi di Pusat Konservasi Tumbuhan Kebun Raya Bogor dengan nomor identifikasi tanaman 6670/IPH.3./KS/XII/2015. Selain itu, bahan lain yang digunakan antara lain 
akuades, air laut, etanol (teknis dan pro analisis), serbuk magnesium, DMSO (dimetil sulfoksida), etil asetat, vitamin $\mathrm{C}$, asam klorida pekat, $\mathrm{FeCl}_{3}$, amonia, $\quad n$ heksana, asam asetat, $n$-butanol, pereaksi Dragendorff, Wagner, Mayer, LiebermannBurchard, plat KLT silika gel 60 $\mathrm{F}_{254}$ (Merck), DPPH (1,1-diphenyl-2picrylhydrazyl), larva Artemia salina L. dengan umur 48 jam.

\section{Identifikasi Senyawa}

a. Uji Flavonoid

Ditimbang 0,5 g sampel ditambahkan 2mg serbuk Mg, lalu ditambahkan 3 tetes $\mathrm{HCl}$ pekat. Apabila terbentuk warna orange, merah atau kuning menunjukkan adanya flavonoid (Harborne, 1987).

b. Uji Fenolik

Ditimbang 0,5 g sampel lalu dilarutkan dengan air $5 \mathrm{ml}$. Kemudian ditambahkan beberapa tetes larutan $\mathrm{FeCl}_{3}$, jika terjadi perubahan warna hijau tua atau biru menunjukkan adanya senyawa fenolik (Harborne, 1987).

c. Uji Saponin

Saponin dapat dideteksi dengan uji busa dalam air panas.Busa yang stabil terlihat selama 5 menit dan tidak hilang pada penambahan 1 tetes $\mathrm{HCl} 2 \mathrm{~N}$ menunjukkan adanya saponin (Harborne, 1987).

d. Uji Steroid/Triterpenoid
Sebanyak 2 g sampel ditambahkan etanol $25 \mathrm{ml}$ lalu dipanaskan dan di-saring. Filtrat diuapkan kemudian ditambahkan eter.Lapisan eter dipipet dan diuji pada spote plate. Jika ditambahkan pereaksi LiebermannBurchard sebanyak 3 tetes dan terbentuk warna merah/ungu, positif mengandung triterpenoid.Jika terbentuk warna hijau, maka positif mengandung steroid (Harborne, 1987).

e. Uji Alkaloid

Sebanyak 0,5 g sampel dilarutkan dengan etanol dan ditetesi dengan $\mathrm{HCl}$ dan disaring. Kemudian filtrat diuji dengan menambahkan satu atau dua tetes pereaksi Mayer, Wagner dan Dragendorff dalam tabung reaksi yang berbeda. Reaksi positif ditandai dengan adanya endapan putih atau kekuningan pada pereaksi Mayer, endapan coklat pada pereaksi Wagner, dan adanya endapan orange pada pereaksi Dragendorff (Depkes, 1995).

f. Uji Tanin

Sampel ditambahkan $10 \mathrm{ml}$ akuades, disaring dan filtratnya ditambahkan reagen $\mathrm{FeCl}_{3}$. Warna biru tua atau hitam menunjukkan adanya tanin (Harborne, 1987).

\section{Profil Kromatografi Lapis Tipis}

Ekstrak Etanol daun hantap ditotolkan pada plat silika gel $60 \mathrm{~F}_{254}$ 
dengan pipa kapiler hingga 2 kali penotolan.Chamber diisi dengan fase gerak yang sesuai. Pada identifikasi flavonoid, tanin, dan alkaloid menggunakan fase gerak $n$-butanol-amonia (5:0,5), sedangkan untuk steroid menggunakan fase gerak $n$-heksanaetil asetat (1,5:1).

Plat silika dimasukkan ke dalam chamber dan dielusi sampai batas atas. Plat tersebut diambil dan diangin-anginkan, kemudian plat diperiksa dibawah lampu $\mathrm{UV}_{254} \mathrm{~nm}$ dan $\mathrm{UV}_{366} \mathrm{~nm}$. Selanjutnyaplat disemprot dengan pereaksi semprot, untuk flavonoid menggunakan pereaksi alumunium klorida $1 \%$, tanin menggunakan pereaksi $\mathrm{FeCl}_{3}$, alkaloid menggunakan pereaksi Dragendorff dan untuk identifikasi steroid menggunakan pereaksi Liebermann-Burchard (Harborne, 1987; Waksmundzka-Hajnos et al., 2008).

\section{Uji Aktivitas Antioksidan}

a. Pembuatan Larutan Induk DPPH

Ditimbang 4,929 mg DPPH, dimasukkan dalam labu ukur $25 \mathrm{ml}$, lalu ditambah etanol pro analisis sampai tanda batas dan dihomogenkan (Sekarsari dan Taufikurrohmah, 2012).

b. Pembuatan Larutan Blanko

Dipipet sebanyak $5 \mathrm{ml}$ larutan DPPH induk, dimasukkan ke dalam labu ukur lalu ditambahkan etanol hingga $25 \mathrm{ml}$ (Molyneux et al.,2004)

c. Pengukuran Serapan Blanko
Dipipet $4 \mathrm{ml}$ larutan blanko, kemudian dihomogenkan dan dibiarkan selama 30menit, selanjutnya diukur serapannya pada panjang gelombang $517 \mathrm{~nm}$.

d. Larutan Pembanding Vitamin C

Ditimbang Vitamin C sebanyak $10 \mathrm{mg}$. Dilarutkan dengan air bebas $\mathrm{CO}_{2}$ secukupnya lalu ditambahkan etanol hingga $10 \mathrm{ml}$,sehingga konsentrasi yang diperoleh yaitu $1.000 \mathrm{ppm}$. Dipipet $1 \mathrm{ml}$ dan dimasukkan ke dalam labu ukur 10 $\mathrm{ml}$. Ditambahkan 1,5 ml larutanDPPH dengan etanol hingga diperoleh konsentrasi 0,01 ppm, 0,1 ppm, 1 ppm dan 10 ppm. Dari masing-masing konsentrasi dipipet $4 \mathrm{ml}$, didiamkan selama 30 menit kemudian diukur absorbansinya pada panjang gelombang $517 \mathrm{~nm}$. Dilakukan perlakuan yang sama untuk pembuatan Larutan Uji.

\section{Pengukuran Absorbansi}

Setelah diperoleh nilai absorbansinya, persen hambatan masingmasing larutan dihitung dengan

$\%$ Hambatan $=($ Abs blanko-Abs sampel $) \times 100 \%$

Abs blanko

menggunakan rumus (Molyneux et al., 2004).

Setelah mendapat persentase aktivitas hambatan, kemudian dihitung nilai $\mathrm{IC}_{50}$ ekstrak. 


\section{Uji Sitotoksik dengan BSLT}

a. Penetasan Telur

Disiapkan air laut secukupnya kemudian disaring.Telur Artemia salina $\mathrm{L}$. dimasukkan di dalam wadah penetas telur.Penetesan dilakukan dengan caramenaburkan telur pada penetesan yang telah dialiri udaradengan aerator, kemudian diberi penerangan lampu selama24-48 jam (Mudjiman, 1989).

b. Pembuatan Larutan Uji

Sebanyak 0,5 g ekstrak dilarutkan dalam 5 tetes DMSO (Dimetil Sulfoksida) dipipet ke dalam flakon sebanyak 500 $\mu \mathrm{l}, 250 \mu \mathrm{l}, 125 \mu \mathrm{l}, 50 \mu \mathrm{l}$, dan $25 \mu \mathrm{l}$. Ditambahkan air laut sampai dengan volume akhir $10 \mathrm{ml}$, sehingga didapatkan hasil akhir larutan uji dengan kadar 1000 ppm, 500 ppm, 250 ppm, 100 ppm, dan $50 \mathrm{ppm}$. Masing-masing flakon dimasuk-kan 10 ekor larva A.salina L. dan ditambahkan 1 tetes suspensi ragi (3 $\mathrm{mg}$ ragi dalam $5 \mathrm{ml}$ air laut) sebagai makanan, lalu dibiarkan selama 24 jam. Setelah 24 jam dihitung larva yang mati. Setelah diketahui persen kematian kemudian ditentukan nilai $\mathrm{LC}_{50}$ ekstrak.Suatu senyawa dinyatakan aktif apabila memiliki nilai $\mathrm{LC}_{50} \leq 500$ (Meyer et al., 1982).

\section{Analisis Data}

\section{a.Pengukuran Aktivitas Antioksidan}

Berdasarkan data persen peredaman radikalDPPH (persen hambatan) yang diperoleh, selanjutnya dianalisis dan dihitung nilai IC $_{50}$ ekstrak. Semakin kecil nilai $\mathrm{IC}_{50}$ berarti aktivitas antioksidan semakin kuat.Nilai $\mathrm{IC}_{50}$ dianalisis dan dihitung secara manual menggunakan kalkulator.

\section{b. Uji Sitotoksik}

Menurut Meyer et al., (1982) efek sitotoksik in vitro senyawa bioaktif terhadap A.salina L. dianalisis menggunakan analisis probit dengan menghitung persentase kematian larva uji setelah 24 jam perlakuan dengan rumus sebagai berikut:

\section{$\%$ kematian = Jumlah larva Artemia salina L. mati $x$ 100\% Jumlah larva uji}

Data persentase kematian larva A.salina L. digunakan untuk mencari angka probit melalui tabel dan dibuat persamaan regresi linier menggunakan program komputer, sehingga diperoleh persamaan sebagai berikut :

$$
\mathrm{Y}=\mathrm{a}+\mathrm{bx}
$$

Dimana $\mathrm{y}=$ angka probit, dan $\mathrm{x}=\log$ konsentrasi.

Persamaan tersebut dapat digunakan untuk mengetahui nilai $\mathrm{LC}_{50-24}$ jam komponen ekstrak daun hantap dengan 
memasukkan nilai probit 5 (50\% kematian).

Jika terjadi kematian A.salina L. pada kelompok kontrol (konsentrasi $\quad 0 \mathrm{~g} / \mathrm{ml}$ ) maka dapat dikoreksi dengan rumus Aboot menurut Meyer et al., (1982), yaitu:

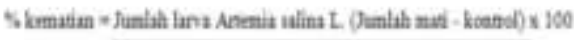
fualah lans of

Apabila diketahui $\mathrm{LC}_{50-24}$ jam dari sampel yang diujikan di bawah $1000 \mathrm{~g} / \mathrm{ml}$, maka komponen yang terkandung pada sampel tersebut dapat dinyatakan toksik dan memiliki aktivitas sitotoksik menurut BSLT (Meyer et al., 1982).

\section{HASIL DAN PEMBAHASAN}

\section{Hasil Uji Antioksidan}

Hasil pengujian antioksidan ekstrak etanol daun hantap (S.coccinea Jack.) dan kontrol positif dapat dilihat pada tabel 1 berikut.

Tabel 1. Aktivitas antioksidan ekstrak etanol daun hantap

\begin{tabular}{|c|c|c|c|c|c|c|c|}
\hline \multirow{2}{*}{ Senpel. } & \multirow{2}{*}{ Beplitai } & \multicolumn{4}{|c|}{ Serthmin } & \multirow{2}{*}{$\begin{array}{l}\text { Cai } \\
x_{5}\end{array}$} & \multirow{2}{*}{$\begin{array}{l}\text { Rana } \\
\mathrm{x}_{\mathrm{a}}\end{array}$} \\
\hline & & का & 01 & 1 & in & & \\
\hline Eutral & I & $27 / 4$ & 393 & 4622 & 6096 & 6,483 & \multirow{4}{*}{6,28} \\
\hline Deat & II & 299 ? & 312 & 4611 & 6101 & 6,490 & \\
\hline \multirow[t]{2}{*}{ Netry } & D & 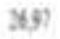 & 39.18 & 4623 & 699 & 6045 & \\
\hline & I & 34.46 & 7994 & 69.92 & B,13 & 26 ? & \\
\hline Vtrain & II & 3136 & 48,51 & 68,9 & 1222 & $2 \pi 3$ & $2 \pi$ \\
\hline C & III & 1136 & 4169 & 7013 & 1251 & 2658 & \\
\hline
\end{tabular}

\section{Hasil Uji Sitotoksik}

Data hasil pengujian sitotoksik ekstrak etanol daun hantap (S.coccinea
Jack.) terhadap larva A.salina L. dapat dilihat pada tabel 2 berikut.

Tabel 2. Aktivitas sitotoksik ekstrak etanol daun hantap

\begin{tabular}{|c|c|c|c|c|}
\hline Konsemras (ugui) & $\begin{array}{c}\text { Isg } \\
\text { Konatrai } \\
(\mathbb{N})\end{array}$ & Renatiandramia & $\begin{array}{l}\mathrm{Maz} \\
\text { Probit } \\
\text { (1) }\end{array}$ & $\begin{array}{l}\mathrm{LC}_{\mathrm{I}} \\
\text { (ugmi) }\end{array}$ \\
\hline 58 & 1,699 & 16 & 401 & \\
\hline 100 & 2 & 24 & 430 & \\
\hline 200 & $239 ?$ & 32 & 453 & $591.56 !$ \\
\hline 500 & 2,699 & 46 & 490 & \\
\hline 100 & 3 & 62 & 531 & \\
\hline
\end{tabular}

\section{Hubungan Mortalitas Artemia salina L. dengan Log Konsentrasi Ekstrak}

Setelah mendapatkan data log konsentrasi dan nilai probit, maka dibuat grafik antara hubungan mortalitas Artemia salina L. dengan konsentrasi daun hantap.

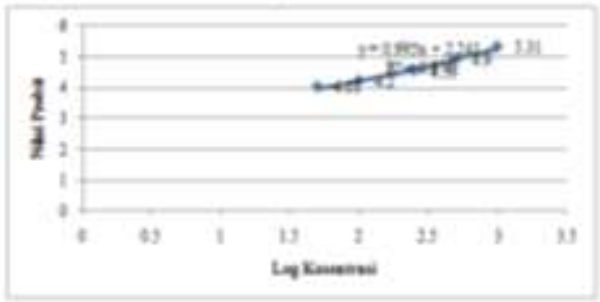

Gambar 1. Grafik hubungan mortalitas Artemia Salina L. dengan log konsentrasi daun hantap

\section{Hasil Identifikasi Golongan Senyawa}

Hasil identifikasi golongan senyawa pada ekstrak etanol daun hantap dapat dilihat pada tabel 3 berikut. 
Tabel 3. Hasil identifikasi golongan senyawa ekstrak dengan pereaksi identifikasi

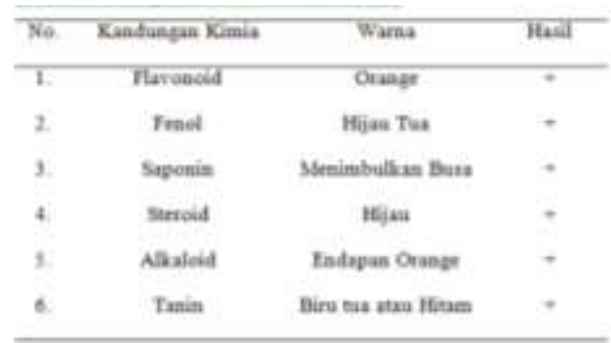

\section{Hasil KLT Ekstrak Etanol Daun Hantap}

a. Identifikasi Senyawa Tanin

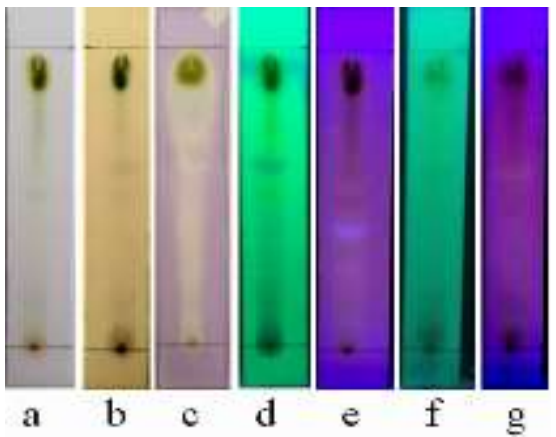

Gambar 2. Hasil KLT identifikasi senyawa tanin, eluen $n$-butanol : amonia $(5: 0,5)$

Keterangan :

a.Visualisasi sinar tampak

b.Visualisasi setelah semprot $\mathrm{FeCl}_{3}$

c.Visualisasi setelah semprot DPPH

d.Visualisasi sebelum semprot $\mathrm{FeCl}_{3}$

pada lampu $\mathrm{UV}_{254} \mathrm{~nm}$

e.Visualisasi sebelum semprot pada

lampu $\mathrm{UV}_{366} \mathrm{~nm}$

f. Visualisasi setelah semprot $\mathrm{FeCl}_{3}$ pada

lampu $\mathrm{UV}_{254} \mathrm{~nm}$

g.Visualisasi setelah semprot $\mathrm{FeCl}_{3}$ pada

lampu $\mathrm{UV}_{366} \mathrm{~nm}$

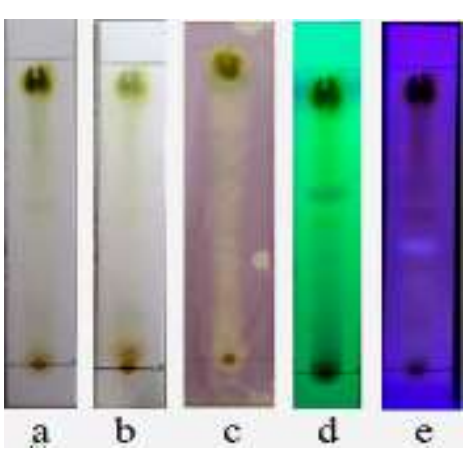

Gambar 3. Hasil KLT identifikasi senyawa flavonoid, eluen $n$-butanol : amonia $(5: 0,5)$ Keterangan :

a. Visualisasi sinar tampak

b.Visualisasi setelah semprot $\mathrm{AlCl}_{3}$

c.Visualisasi setelah semprot DPPH

d.Visualisasi sebelum semprot $\mathrm{AlCl}_{3}$

pada lampu $\mathrm{UV}_{254} \mathrm{~nm}$

e.Visualisasi sebelum semprot

$\mathrm{AlCl}_{3}$ pada lampu $\mathrm{UV}_{366} \mathrm{~nm}$

\section{c.Identifikasi Senyawa Steroid}

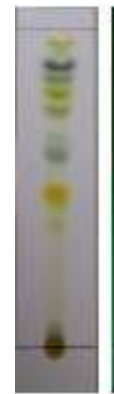

a

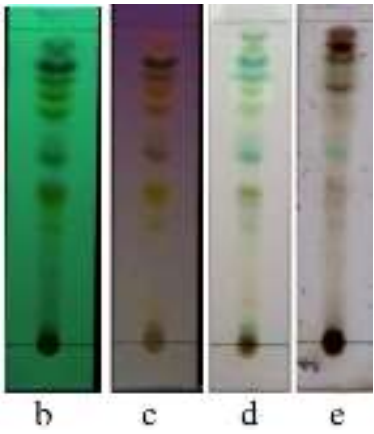

Gambar 4. Hasil KLT identifikasi senyawa steroid, eluen $n$-heksana-etil asetat $(1,5: 1)$

Keterangan :

a. Visualisasi sinar tampak

b.Visualisasi pada lampu $\mathrm{UV}_{254} \mathrm{~nm}$

c.Visualisasi pada lampu $\mathrm{UV}_{366} \mathrm{~nm}$

d.Visualisasi setelah semprot

Liebermann-Burchard dan dipanaskan

\section{b. Identifikasi Senyawa Flavonoid}

Aktivitas Antioksidan dan Sitotoksik Ekstrak Etanol Daun hantap (Sterculia coccinea Jack.)

(Rezki Cahyani) 
e.Visualisasi setelah semprot asam sulfat $20 \%$ dan dipanaskan

\section{d. Identifikasi Senyawa Alkaloid}

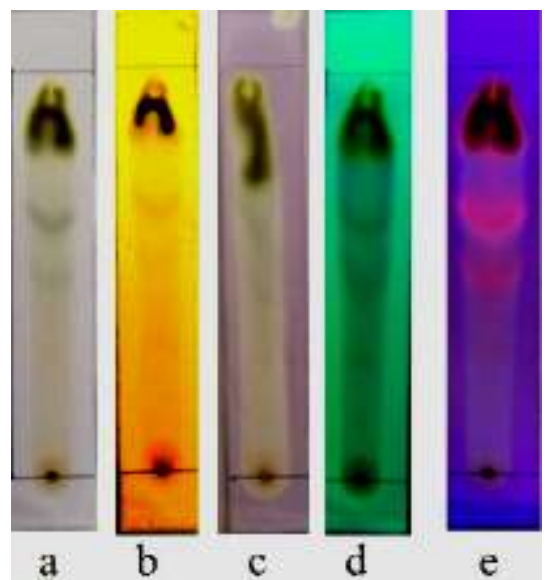

Gambar 5. Hasil KLT identifikasi senyawa alkaloid, eluen $n$-butanol : amonia $(5: 0,5)$

Keterangan:

a.Visualisasi sinar tampak sebelum disemprot Dragendorff

b.Visualisasi setelah semprot

\section{Dragendorff}

c.Visualisasi setelah semprot DPPH

d.Visualisasi sebelum disemprot

Dragendorff pada lampu $\mathrm{UV}_{254} \mathrm{~nm}$

e.Visualisasi sebelum disemprot

Dragendorff pada lampu UV $\mathrm{UV}_{366} \mathrm{~nm}$.

\section{Pembahasan}

Pada proses maserasi serbuk daun hantap dengan etanol $96 \%$ diperoleh berat ekstrak kental sebesar 25,33 g dengan persen rendemen $7,237 \%$.

Setelah diperoleh ekstrak etanol daun hantap dilakukan uji kromatografi lapis tipis pada plat silika $\mathrm{GF}_{254}$ dengan 2 kali penotolan. Fase gerak yang digunakan pada identifikasi golongan senyawa flavonoid, tanin dan alkaloid adalahn-butanol-amonia (5:0,5), sedangkan untuk steroid menggunakan fase gerak $n$-heksana-etil asetat $(1,5: 1)$.

Hasil analisis kualitatif dengan menggunakan kromatografi lapis tipis ekstrak etanol daun hantap (S.coccinea Jack.) menunjukkan bahwa kromatogram ekstrak etanol untuk pengamatan senyawa tanin setelah disemprot $\mathrm{FeCl}_{3}$ menunjukan bercak berwarna abu-abu kecoklatan. Menurut Banu dan Nagarajan (2014) hasil tersebut dapat dikatakan positif mengandung senyawa tanin.Identifikasi senyawa flavonoid secara sinar tampak setelah disemprot alumunium klorida $1 \%$, menunjukkan adanya bercak berwarna oranye yang berarti positif mengandung flavonoid (Banu dan Nagarajan 2014).Untuk senyawa steroid setelah disemprot pereaksi Liebermann-Burchard menunjukkan adanya dua bercak yang berwarna kuning kehijauan dan satu bercak yang berwarna hijau. Setelah plat dipanaskan selama 3 menit bercak/noda semakin jelas berwarna hijau. Berdasarkan hal tersebut ekstrak positif mengandung senyawa steroid (Monica et al., 2008).Selain hal itu, ekstrak etanol daun hantap juga positif mengandung senyawa alkaloid.Hal ini diketahui setelah plat 
disemprot dengan pereaksi Dragendorff yang menunjukan adanya bercak oranye(Banu dan Nagarajan, 2014).

Hasil uji aktivitas antioksi dan ekstrak etanol daun hantap memiliki aktivitas antioksidan dengan nilai $\mathrm{IC}_{50}$ yaitu 6,48 ppm, sedangkan vitamin C (kontrol positif) memiliki nilai $\mathrm{IC}_{50}$ yaitu $2,71 \mathrm{ppm}$. Menurut Molyneux et al., (2004) semakin kecil nilai $\mathrm{IC}_{50}$ maka semakin besar potensi aktivitas antioksidan. Berdasarkan hal itu,dapat dikatakan vitamin $\mathrm{C}$ memiliki aktivitas antioksidan yang lebih kuat dibandingkan dengan ekstrak etanol daun hantap.Meskipun demikian, menurutBlois (1958) ekstrak dikatakan memiliki potensi antioksidan termasuk kategori sangat kuat yaitu $<50$ ppm.

Aktivitas antioksidan ekstrak etanol daun hantap diduga disebabkan oleh adanya senyawa bioaktif yang dapat menangkap radikal bebas DPPH seperti senyawa flavonoid.Senyawa flavonoid dapat meredam aktivitas radikal hidroksil, superoksida serta antilipoperoksidan (Sidana et al., 2013).

Senyawa flavonoid merupakan komponen polifenol yang terdapat pada banyak tanaman. Flavonoid diketahui mampu menangkap radikal bebas (ROS/Reactive Oxygen Species atau RNS/Reactive Nitrogen Species) melalui transfer elektron, serta menghambat reaksi peroksidasi (Lugasiet al., 2003). Selain itu, senyawa flavonoid merupakan pengkhelat logam dan dapat menghambat reaksi fenton yang penting sebagai sumber radikal oksigen reaktif (Shahidi dan Wanasundara, 1992).

Untuk menentukan aktivitas sitotoksik dari ekstrak etanol daun hantap digunakan metode Brine Shirimp Lethality Test (BSLT). Pada proses pengujiannya menggunakan larva A.Salina L. yang telah ditetaskan terlebih dahulu selama 48 jam dalam air laut. Alasan digunakan larva yang berumur 48 jam karena organ-organ A.salina L. sudah terbentuk lengkap (Sorgeloos, 1973). Dengan terbentuknya mulut, A.salina L. dapat meminum air laut yang telah diberi ekstrak daun hantap (berbagai kosentrasi), sehingga dapat dinyatakan bahwa kematian A.salina L. adalah benar disebabkan oleh ekstrak daun hantap dalam berbagai kosentrasi tersebut (Novita, 2013).

Berdasarkan hasil penelitian yang dilakukan didapatkan nilai $\mathrm{LC}_{50}$ ekstrak etanol daun hantap melalui uji Brine Shirimp Lethality Test (BSLT) terhadap larva A.salina L. sebesar 591,561 ppm.Berdasarkan pendapat yang disampaikan oleh Meyer (1982), suatu ekstrak dikatakan berpotensi antikanker jika memiliki nilai $\mathrm{LC}_{50} \leq 1000$ ppm.Hasil 
ini juga sesuai dengan tingkat nilai toksisitas $\mathrm{LC}_{50}$ yang disampaikan oleh Anderson et al., (1991), yaitu ekstrak yang berada pada kisaran 500-750 $\mu \mathrm{g} / \mathrm{ml}$ bersifat memiliki toksisitas yang sedang.Berdasarkan pendapat diatas, maka dapat disimpulkan bahwa ekstrak etanol daun hantap (S.coccinea Jack.) memiliki potensi sebagai antikanker.

Adanya kemampuan sitotoksik diduga terjadi karena adanya aktivitas metabolit sekunder yang terdapat dalam ekstrak daun hantap (S.coccinea Jack.) terutama senyawa flavonoid dan tannin.Hal ini didukung dengan hasil uji penapisan fitokimia yang menunjukkan adanya golongan senyawa flavonoid dan tanin. Dimana pada kadar tertentu memiliki potensi toksisitas serta dapat menyebabkan kematian larva (Arter dkk., 2013).

\section{UCAPAN TERIMA KASIH}

Ucapan terima kasih disampaikan kepada Dr.rer. hort. Reni Lestari, M.Sc selaku plh Kepala Pusat Konservasi Tumbuhan Kebun Raya yang telah mengidentifikasi tumbuhan yang digunakan sebagai sampel pada penelitian ini.

\section{DAFTAR PUSTAKA}

Anderson, J. E., Goetz C. M., and Mc Laughlin J. L., 1991, A Blind Comparison of Simple Bench-top Bioassay and Human Tumor Cell
Cytotoxicities as Antitumor Prescrenss, Natural Product Chemistry, Elseiver, Amsterdam.

Arter D. M., Harry S.J.K., Max R.J.R., 2013,Uji toksisitas dengan Metode BSLT dan Analisis Kandungan Fitokimia Ekstrak Daun Soyogik (Saurauia bracteosa DC) dengan Metode Soxhletasi, Jurusan KimiaFMIPA, Universitas Samratulangi, Manado.

Blois, MS., 1958, Antioxidant Determinations, By The Use of a Stable Free Radical Nature: 199-200.

Depkes RI., 1995, Farmakope Indonesia Edisi IV, Departemen Kesehatan RI, Jakarta.

Effendi, N., 2010, Standarisasi Simplisia Daun Hantap (Sterculia coccinea Jack) Asal Kabupaten Donggala Propinsi Sulawesi Tengah Sebagai Bahan Baku Sediaan Fitofarmaka, Fakultas Farmasi, Universitas Muslim Indonesia, Makassar.

Harborne, J.B., 1987, Metode Fitokimia: Penuntun Cara Modern menganalisis Tumbuhan, Terjemahan Kosasih Padmawinata dan Iwang Soediro,Penerbit ITB, Bandung.

Lugasi, A., Hovari, J., Sagi, K. V., Biro, L. (2003), The Role of Antioxidant Phytonutrients In The Prevention of Disease. Acta Biologica Szegediensis, 47, 119-125.

Meyer, B.N., Ferrigni, N.R., Putnam, J.E., Jacobsen, L.B., Nicholas, D.E., and McLaughlin, J.1., 1982, Brine Shrimp: A Convenient General Bioassay for Active Plant Constituent, Planta Medica, 31-34.

Molyneux, P., 2004, The Use of Stable Free Radical Diphenylpicrylhidrazyl 
(DPPH) for Estimating Antioxidant Activity, Jurnal Science Technology.

Monica, W.H., Joseph, S., Teresa, K., 2008, Thin Layer Cromatography in Phytochemistry, Cromatographic Science Series Vol.99, CRC Press.

Mudjiman, A., 1989, Udang Renik Air Asin, Bhatara, Jakarta

Novita, D., 2013, Eksplorasi Senyawa Metabolit Sekunder dari Ascidian Didemnum sp. untuk Senyawa Antikanker, Universitas Padjajaran, Bandung.

Banu, R.H. and Nagarajan, N., 2014, TLC and HPTLC Fingerprinting of Leaf Extracts of Wedelia chinensis (Osbeck) Merrill. Journal of Pharmacognosy and phytochemistry, 2(6): 29-33

Sekarsari, R. A. dan Taufikurrohmah, T., 2012,Sintesis dan Karakterisasi Nanogold dengan Variasi Konsentrasi haucl4 Sebagai Material

Antiaging Dalam Kosmetik, Prosiding Seminar Nasional Kimia Unesa 2012, ISBN : 978-979-028-550-7, Surabaya.

Shahidi, F., Wanasundara,(1992), Phenolic Antioxidants.Crit Rev Food Sci Nutr, 32, 67-103.

Sidana J, Saini V, Dahiya S, Nain P,Bala S., 2013, A review on citrus: the boon of nature, Journal pharmacy science review and research 18(2):20-27.

Sorgeloos, P., 1973, First report of the triggering effect of light on the hatching mechanism of Artemia salina dry cysts. Mar. Biol. 22: 75-76.

Waksmundzka-Hajnos, M., Sherma, J., and Kowalska, T., 2008, Thin Layer Chromatography, CRC Press Taylor \& Francis Group, LLC, Boca Raton. 